\title{
PENGEMBANGAN PERANGKAT PEMBELAJARAN INKUIRI TERBIMBING BERBASIS AKTIVITAS HIGHER ORDER THINKING (HOT) PADA TEMA 8 SUBTEMA 1 KELAS V SD
}

\author{
Ni Nyoman Ely Triyuni \\ Program Studi Pendidikan Guru Sekolah Dasar, Universitas Pendidikan Ganesha \\ Email: ely.triyuni70@gmail.com \\ Ni Nyoman Kusmariyatni \\ Program Studi Pendidikan Guru Sekolah Dasar, Universitas Pendidikan Ganesha \\ nym_kusmaryatni@yahoo.co.id \\ I Gede Margunayasa \\ Program Studi Pendidikan Guru Sekolah Dasar, Universitas Pendidikan Ganesha \\ Email: pakgun_pgsd@yahoo.com
}

\begin{abstract}
Abstrak
Penelitian ini bertujuan untuk mengetahui validitas perangkat pembelajaran inkuiri terbimbing berbasis aktivitas higher order thinking (HOT) pada Tema 8 Subtema 1 kelas V SD. Penelitian ini merupakan penelitian pengembangan yang menggunakan model pengembangan ADDIE yang terdiri dari tahap analisis (analyze), tahap perancangan (design), tahap pengembangan (development), tahap implementasi (implementation), dan tahap evaluasi (evaluation), namun penelitian ini hanya sampai pada tahap development. Subjek penelitian terdiri dari dua orang guru dan dua orang dosen sebagai ahli pembelajaran. Objek penelitian ini adalah perangkat pembelajaran inkuiri terbimbing berbasis aktivitas higher order thinking (HOT) yang terdiri dari silabus, RPP, dan LKPD. Pengumpulan data dilakukan dengan metode kuesioner. Instrumen pengumpulan data menggunakan rating scale berupa lembar penilaian perangkat pembelajaran. Data yang diperoleh dianalisis menggunakan statistik deskriptif kualitatif dan kuantitatif. Berdasarkan analisis data diperoleh hasil sebagai berikut: (1) skor rata-rata validitas silabus sebesar 4,69 dengan kualifikasi sangat baik, (2) skor rata-rata validitas RPP sebesar 4,77 dengan kualifikasi sangat baik, (3) skor rata-rata validitas LKPD sebesar 4,84 dengan kualifikasi sangat baik. Berdasarkan hal tersebut, dapat disimpulkan bahwa perangkat pembelajaran inkuiri terbimbing berbasis aktivitas higher order thinking (HOT) pada Tema 8 Subtema 1 kelas V SD memiliki kualifikasi yang sangat baik.
\end{abstract}

Kata kunci: aktivitas higher order thinking, inkuiri terbimbing, perangkat pembelajaran

\begin{abstract}
This study aims to determine the validity of guided inquiry learning devices based on higher order thinking (HOT) activities in Theme 8 of Subthema 1 in class V SD. This research is a development research that uses the ADDIE development model which consists of the analysis stage, the design stage, the development stage, the implementation stage, and the evaluation stage, but this research only reaches development stage. The research subject consisted of two teachers and two lecturers as learning experts. The object of this study is a guided inquiry learning device based on a higher order thinking activity (HOT) which consists of syllabus, lesson plans, and student worksheet. Data collection is done by questionnaire method. The instrument for collecting data uses a rating scale in the form of a learning device assessment sheet. The data obtained were analyzed using qualitative and quantitative descriptive statistics. Based on the analysis of the data obtained the following results: (1) the average score of the syllabus validity of 4,69 with excellent qualifications, (2) the average score of the lesson plans validity of 4,77 with excellent qualifications, (3) the average score the average validity of student worksheet is 4,84 with very good qualifications. Based on this, it can be concluded that the guided inquiry learning tool is based on a higher order thinking activity (HOT) on Theme 8 of Subthema 1 in class $V$ Elementary School which has very good qualifications.
\end{abstract}

Keywords: activities of higher order thinking, guided inquiry, learning tools

\section{Pendahuluan}

Pendidikan di sekolah dasar (SD) merupakan jenjang pendidikan yang sangat penting dan perlu diperhatikan karena pendidikan di SD menjadi dasar bagi pendidikan selanjutnya. Setiap jenjang pendidikan memiliki peranan yang penting dalam keberhasilan siswa dalam menempuh pendidikannya, namun sekolah dasar memiliki peranan yang paling mendasar dalam keberhasilan menuju pendidikan selanjutnya (Ningrat dan Sumantri, 2019). Pendidikan SD bertujuan memberikan bekal kemampuan dasar baca, tulis, hitung, pengetahuan, dan keterampilan dasar yang sesuai dengan tingkat perkembangan serta mem-persiapkan siswa ke jenjang SMP (Susanto, 2013). Berdasarkan hal tersebut, maka setiap pembelajaran di SD perlu diarahkan pada pembentukan fondasi yang kuat untuk terbentuknya konsep dasar yang kuat pada diri siswa. Untuk dapat mencapai tujuan pendidikan dengan optimal maka perlu adanya upaya peningkatan kualitas pendidikan.

Salah satu upaya yang dilakukan pemerintah untuk meningkatkan kualitas pendidikan yaitu dengan melakukan perubahan kurikulum. Kurikulum menempati posisi penting dalam pendidikan, karena berkaitan dengan penentuan arah, isi 
dan proses pendidikan yang berujung pada standar kualifikasi pendidikan (Rudyanto, 2014). Saat ini di Indonesia telah menerapkan kurikulum baru yang bernama Kurikulum 2013 yang memiliki tujuan untuk mempersiapkan individu agar memiliki kemampuan hidup sebagai pribadi yang beriman, produktif, kreatif, inovatif, dan afektif serta mampu berkonstribusi dalam kehidupan, baik bermasyarakat, berbangsa, bernegara, maupun peradaban dunia (Kemendikbud, 2014). Pembelajaran pada Kurikulum 2013 menggunakan pembelajaran berbasis tematik terintegratif yang menggunakan pendekatan saintifik sebagai salah satu cara untuk memberikan pemahaman pada siswa dalam memahami berbagai materi dan mendorong siswa untuk mencari suatu informasi dari berbagai sumber melalui kegiatan mengamati, menanya, mengumpulkan informasi, menalar, dan mengomunikasikan. Pembelajaran dengan pendekatan saintifik dirancang agar peserta didik aktif membangun pengetahuannya melalui tahapan-tahapan mengamati, merumuskan masalah, mengajukan atau merumuskan hipotesis, mengumpulkan data, menganalisis data, menarik kesimpulan dan mengomunikasikan pengetahuan yang ditemukannya (Machin, 2014).

Pembelajaran dengan pendekatan saintifik memiliki beberapa karakteristik yaitu pembelajaran berpusat pada siswa, adanya keterlibatan keterampilan proses sains dalam mengkonstruksi konsep, hukum atau prinsip, merangsang perkembangan intelek khususnya keterampilan berpikir tingkat tinggi siswa dengan melibatkan proses-proses kognitif, dapat mengembangkan karakter siswa. Senada dengan karakteristik tersebut, pembelajaran dengan pendekatan saintifik juga memiliki tujuan, salah satunya yaitu untuk meningkatkan kemampuan intelek, khususnya kemampuan berpikir tingkat tinggi siswa (Daryanto, 2014).

Kemampuan berpikir tingkat tinggi (higher order thinking skill) merupakan suatu proses berpikir yang bukan sekedar menghafal dan menyatakan kembali informasi yang diketahui. Kemampuan berpikir tingkat tinggi merupakan kemampuan dalam menghubungkan, memanipulasi, dan mentransformasi pengetahuan serta pengalaman yang telah dimiliki untuk berpikir kritis dan kreatif dalam upaya menentukan keputusan dan memecahkan permasalahan pada situasi baru (Rofiah, dkk., 2013). Kemampuan higher order thinking (HOT) meliputi kemampuan berpikir kritis, kreatif, metakognisi dan pemecahan masalah (Jamaluddin, dkk., 2018). Kemampuan berpikir tingkat tinggi merupakan salah satu modal terpenting yang harus dimiliki oleh individu (Sutrisno dan Retnawati, 2018). Kemampuan berpikir tingkat tinggi dapat membantu individu dalam memecahkan masalah, menentukan keputusan, dan mengambil tindakan dalam aktivitas kehidupannya. Kemampuan berpikir yang ditunjukkan dengan berpikir tingkat tinggi seharusnya dapat dikembangkan dalam pembelajaran.

Kenyataannya, perangkat pem-belajaran yang digunakan khususnya di SD pada Gugus XIII Kecamatan Buleleng belum sesuai dengan Permendikbud No. 22 Tahun 2016. Hal tersebut didasarkan pada hasil analisis perangkat pembelajaran yang digunakan guru menunjukkan bahwa: (1) kegiatan pembelajaran pada silabus belum mencerminkan adanya pengembangan kemampuan HOT, (2) sumber belajar pada silabus tidak sesuai dengan materi pokok, (3) sistematika rencana pelaksanaan pem-belajaran (RPP) yang disusun belum sesuai, yakni masih mencantumkan pada setiap RPP yang disusun, (4) rumusan indikator pada RPP dibuat sama seperti kompetensi dasar, (5) indikator yang dirumuskan cenderung pada aspek kognitif tingkat dasar, (6) instrumen penilaian pada RPP belum lengkap dan belum mengukur kemampuan HOT siswa, (7) langkah-langkah pembelajaran belum men-cerminkan adanya aktivitas HOT, (8) tidak terdapat lembar kerja peserta didik (LKPD) yang digunakan dalam pembelajaran, (9) guru hanya mengambil soal-soal pada buku paket untuk memberikan latihan pada siswa.

Berdasarkan hasil wawancara yang dilakukan dengan guru kelas V SD di Gugus XIII Kecamatan Buleleng pada 1822 Januari 2019, perangkat pembelajaran berupa silabus dan RPP yang digunakan merupakan hasil dari kelompok kerja guru (KKG), sehingga perangkat yang digunakan pada gugus tersebut sama. Dengan demikian, maka diperlukan adanya upaya yang dapat meningkatkan kualitas pembelajaran.

Salah satu upaya yang dapat dilakukan yaitu mengembangkan perangkat pembelajaran yang dapat memberikan situasi belajar yang baru, sehingga siswa dirangsang rasa ingin tahunya dan termotivasi dalam mengikuti pembelajaran. Pengembangan perangkat pembelajaran ini dapat dipadukan dengan menerapkan model pembelajaran yang mendukung demi terciptanya perangkat pembelajaran yang lebih baik. Model pembelajaran yang dimaksud adalah model pembelajaran inkuiri.

Model inkuiri terdiri atas tiga jenis berdasarkan besarnya intervensi guru atau bimbingan yang diberikan oleh guru kepada siswa. Ketiga jenis model inkuiri tersebut adalah sebagai berikut. 1) Inkuiri terbimbing, pembelajaran dengan model inkuiri terbimbing yaitu guru membimbing siswa dalam melaksanakan kegiatan dengan memberi pertanyaan awal dan mengarahkan pada suatu diskusi. Guru mempunyai peran aktif dalam menentukan permasalahan dan tahap-tahap pemecahannya. Model ini digunakan bagi siswa yang kurang berpengalaman belajar dengan model inkuiri. 2) Inkuiri bebas menempatkan siswa seolah-olah bekerja seperti seorang ilmuwan. Siswa diberi kebebasan dalam menentukan permasalahan untuk diselidiki, menemukan dan menyelesaikan masalah secara mandiri, merancang prosedur atau langkah-langkah yang diperlukan. 3) Inkuiri bebas yang dimodifikasikan merupakan kolaborasi atau modifikasi dari dua model inkuiri sebelumnya, yaitu model inkuiri terbimbing dan inkuiri bebas (Jauhar, 2011).

Berdasarkan pengertian dan uraian dari ketiga jenis pembelajaran dengan model inkuiri, penulis memilih model inkuiri terbimbing yang akan digunakan dalam penelitian ini. Model inkuiri terbimbing merupakan salah satu model yang menekankan pada keterampilan sains, kemampuan berpikir, dan penyelidikan ilmiah (Nasution, 2018). Model pembelajaran inkuiri terbimbing merupakan model pembelajaran yang memberikan kesempatan pada siswa dalam membangun pengetahuannya. Kesempatan yang dimaksud adalah siswa diberikan kebebasan mengembangkan gagasannya, merumuskan masalah, merancang percobaaan, sampai dengan membuat kesimpulan dengan bahasa sendiri dan tentunya dengan pemberian motivasi oleh guru dan arahan-arahan yang dapat membantu siswa untuk lebih fokus pada topik yang dipelajari.

Model pembelajaran inkuiri terbimbing ini dapat disinergikan dengan aktivitas higher order thinking (HOT) untuk menumbuhkan kemampuan berpikir kritis, logis, dan sistematis. Aktivitas HOT merupakan kegiatan-kegiatan baik secara fisik maupun mental yang menuntut adanya kemampuan berpikir tingkat tinggi. Pengembangan perangkat pembelajaran inkuiri terbimbing berbasis aktivitas HOT memberikan keuntungan bagi peserta didik, yaitu informasi yang dipelajari dan diproses melalui proses berpikir tingkat tinggi menguatkan ingatan terhadap informasi tersebut, dan lebih jelas dibandingkan dengan informasi yang diproses dengan low order thinking (LOT), misalnya menghafal. Melalui pembelajaran 
dengan aktivitas HOT peserta didik tidak hanya menghafal tetapi juga memahami dan mampu menerapkan dalam kehidupan sehari-hari. Dengan demikian pengetahuan yang diperoleh peserta didik dapat bertahan dalam jangka waktu yang lama.

Proses pembelajaran dengan inkuiri terbimbing berbasis aktivitas HOT meng-ikuti langkah-langkah sebagai berikut. 1) Orientasi, mengkondisikan siswa agar siap mengikuti pembelajaran. siswa diberikan kesempatan untuk melakukan orientasi terhadap suatu situasi (permasalahan). 2) Merumuskan masalah, siswa diarahkan pada suatu permasalahan agar dapat merumuskan masalah. 3) Mengajukan hipotesis, siswa diberikan kesempatan untuk berpendapat dalam merumuskan hipotesis. 4) Mengumpulkan data, siswa mengumpulkan dan mencari informasi melalui kegiatan inkuiri dengan aktivitas HOT. 5) Menguji hipotesis, siswa menentukan jawaban sesuai dengan data dan informasi yang diperoleh melalui kegiatan inkuiri dengan aktivitas HOT. 6) Merumuskan kesimpulan, siswa merumuskan kesimpulan secara sistematis dan logis mengenai per-masalahan yang diberikan.

Penelitian ini memiliki tujuan yaitu untuk mengetahui validitas perangkat pembelajaran inkuiri terbimbing berbasis aktivitas higher order thinking (HOT) pada Tema 8 Subtema 1 kelas V SD di Gugus XIII Kecamatan Buleleng.

\section{Metode}

Penelitian ini merupakan penelitian pengembangan perangkat pembelajaran inkuiri terbimbing berbasis aktivitas HOT yang terdiri dari silabus, RPP dan LKPD. Penelitian ini menggunakan model pengembangan ADDIE (analyze, design, development, implementation, evaluation). Penggunaan model pengembangan ADDIE pada penelitian ini hanya dilaksanakan sampai tahap pengembangan, sedangkan tahap implementasi dan evaluasi tidak dilakukan karena keterbatasan waktu penelitian. Pemilihan model ADDIE didasari pertimbangan bahwa model tersebut mudah dimengerti, dikembangkan secara sistematik, berpijak pada landasan teoretis desain pembelajaran. Model ini disusun secara terprogram dengan urutanurutan kegiatan yang sistematis dalam upaya pemecahan masalah belajar yang berkaitan dengan sumber belajar yang sesuai karakteristik siswa. (Tegeh \& Jampel, 2017).

Pengembangan perangkat pem-belajaran dalam penelitian ini dilakukan dengan serangkaian kegiatan sebagai berikut. 1) Tahap analisis, meliputi analisis kebutuhan, analisis karateristik siswa, dan analisis kurikulum. Tahap ini dilakukan untuk memperoleh informasi sebagai bahan perancangan perangkat pembelajaran. 2) Tahap perancangan yaitu merancang perangkat pembelajaran yang disesuaikan ber-dasarkan hasil analisis yang telah di-lakukan. 3) Tahap pengembangan meliputi kegiatan seperti: (a) pengembangan terhadap perangkat pembelajaran yang sudah dikonsultasikan dengan dosen pembimbing serta melakukan perbaikan terhadap kekurangan yang terdapat pada draft, (b) kegiatan validasi perangkat pembelajaran oleh ahli, (c) menganalisis validitas perangkat pembelajaran.

Subjek dalam penelitian ini adalah ahli pembelajaran yang terdiri dari dua orang guru dan dua orang dosen yang bertugas menilai perangkat pembelajaran yang telah dikembangkan. Metode pengumpulan data yang digunakan dalam penelitian ini adalah metode kuesioner. Instrumen pengumpulan data yang di-gunakan meliputi lembar penilaian perangkat pembelajaran untuk silabus, RPP dan LKPD. Data yang dikumpulkan adalah data hasil validasi perangkat pembelajaran dan saran masukan oleh para ahli dan para praktisi pembelajaran.

Dalam penelitian pengembangan ini digunakan dua teknik analisis data, yaitu teknik analisis deskriptif kualitatif dan teknik analisis deskriptif kuantitatif. Teknik analisis statistik deskriptif kualitatif digunakan untuk mengolah data berupa masukan, tanggapan, kritik, dan saran hasil review dosen dan guru terhadap perangkat pembelajaran yang dikembangkan melalui pemberian rubrik penilaian perangkat pembelajaran. Teknik analisis statistik deskriptif kuantitatif digunakan untuk menganalisis data berupa skor yang didapatkan melalui pemberian kuesioner penilaian perangkat pembelajaran. Skor yang diperoleh dari penilaian perangkat pembelajaran kemudian dihitung rata-ratanya untuk mengetahui validitas perangkat pembelajaran yang dikembangkan.

Uji validitas yang dilakukan meliputi uji validitas instrumen penilaian dan uji validitas produk perangkat pembelajaran. Data uji validitas diperoleh dari hasil penilaian dari para ahli. Tujuan dari uji validitas ini adalah untuk mengukur valid atau tidaknya instrumen rubrik penilaian dan produk perangkat pembelajaran yang dikembangkan.

Rumus yang digunakan untuk mengukur validitas instrumen rubrik penilaian perangkat pembelajaran adalah rumus validitas isi menurut Gregory. Validitas instrumen rubrik penilaian perangkat pembelajaran minimal berada pada rentang skor 0,40-0,59 dengan kriteria validitas isi "sedang". Setelah memenuhi syarat validitas, maka instrumen rubrik penilaian perangkat pembelajaran tersebut dapat digunakan oleh guru dan dosen sebagai ahli pembelajaran dalam melakukan penilaian terhadap produk perangkat pembelajaran berupa silabus, RPP, dan LKPD inkuiri terbimbing berbasis aktivitas HOT yang telah dikembangkan.

Skor yang diperoleh dari hasil penilaian terhadap produk perangkat pembelajaran, kemudian dihitung dan dianalisis validitasnya dengan bantuan microsoft excel dan menggunakan rumus mencari rata-rata atau mean. Setelah diketahui skor rata-ratanya, kemudian skor yang diperoleh dikonversikan dengan pedoman konversi skala lima. Skor validitas perangkat pembelajaran minimal berada pada rentang $2,66<\mathrm{x} \leq 3,33$ dengan kualifikasi "cukup".

\section{Hasil dan Pembahasan}

Penelitian ini menghasilkan perangkat pembelajaran berupa silabus, RPP, dan LKPD inkuiri terbimbing berbasis aktivitas higher order thinking (HOT) pada Tema 8 Subtema 1 untuk kelas V SD yang telah memiliki validitas dengan kualifikasi sangat baik. Hasil tersebut diperoleh melalui tahap pengembangan dan validasi oleh guru dan dosen sebagai ahli pembelajaran yang menilai perangkat pembelajaran yang telah dikembangkan. Data hasil uji validitas perangkat pembelajaran selanjutnya dianalisis untuk mengetahui validitas masing-masing produk yang telah dikembangkan. Analisis data dilakukan dengan menghitung perolehan skor yang didapatkan melalui pemberian rubrik penilaian perangkat pembelajaran yang dijadikan acuan oleh guru dan dosen sebagai ahli pembelajaran dalam melakukan penilaian terhadap perangkat pembelajaran berupa sialbus, RPP, dan LKPD yang dikembangkan. 
Rangkuman hasil analisis validitas perangkat pembelajaran yang dikembang-kan dalam penelitian ini adalah sebagai berikut. Validitas silabus, berdasarkan kegiatan analisis yang telah dilakukan terhadap hasil penilaian produk silabus oleh keempat orang ahli maka diperoleh rata-rata skor validitas silabus yaitu sebesar 4,69. Skor tersebut kemudian dikonversikan pada tabel pedoman konversi skala lima, dimana skor 4,69 berada pada rentang skor $4,01<\mathrm{x} \leq 5,01$. Hal tersebut menunjukkan bahwa perangkat pembelajaran berupa silabus inkuiri terbimbing berbasis aktivitas HOT yang dikembangkan memiliki validitas dengan kualifikasi "sangat baik".

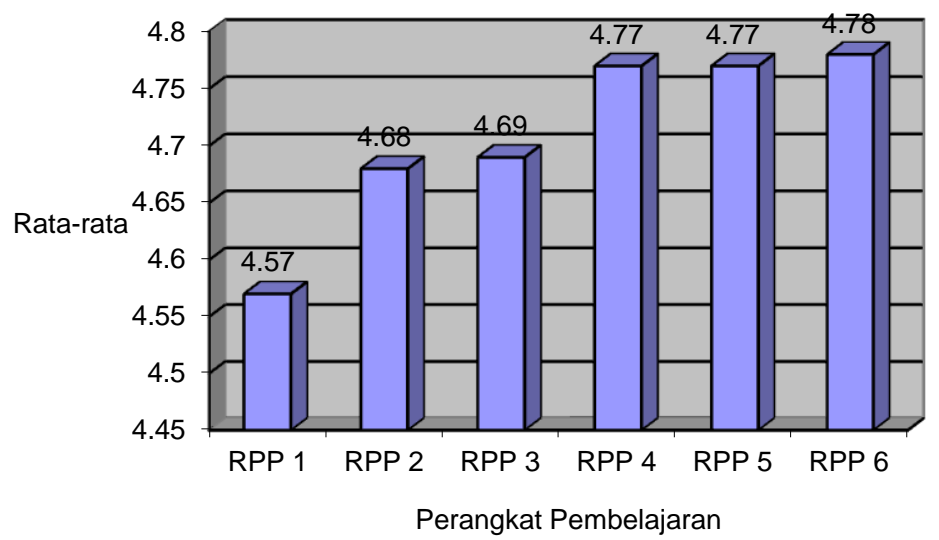

Gambar 1. Skor rata-rata validitas RPP

Validitas RPP dapat dilihat melalui grafik yang disajikan pada Gambar 1. Berdasarkan pada grafik di atas, maka dapat diketahui rata-rata skor validitas dari masing-masing produk RPP yang dikembangkan dalam penelitian sebagai berikut. 1) Rata-rata skor yang diperoleh pada RPP 1 yaitu sebesar 4,57, apabila dikonversikan pada pedoman konversi skala lima, maka skor berada pada rentang 4,01 $<\mathrm{x} \leq 5,01$ dengan kualifikasi "sangat baik". 2) Rata-rata skor yang diperoleh pada RPP 2 sebesar 4,68 apabila dikonversikan pada pedoman konversi skala lima, maka skor berada pada rentang 4,01<x $\leq 5,01$ dengan kualifikasi "sangat baik". 3) Rata-rata skor yang diperoleh pada RPP 3 sebesar 4,69 apabila dikonversikan pada pedoman konversi skala lima, maka skor berada pada rentang 4,01<x $\leq 5,01$ dengan kualifikasi "sangat baik". 4) Rata-rata skor yang diperoleh pada RPP 4 sebesar 4,77 apabila dikonversikan pada pedoman konversi skala lima, maka skor berada pada rentang 4,01 $<\mathrm{x} \leq 5,01$ dengan kualifikasi "sangat baik". 5) Rata-rata skor yang diperoleh pada RPP 5 sebesar 4,77 apabila dikonversikan pada pedoman konversi skala lima, maka skor berada pada rentang 4,01<x $\leq 5,01$ dengan kualifikasi "sangat baik". 6) Rata-rata skor yang diperoleh pada RPP 6 sebesar 4,78 apabila dikonversikan pada pedoman konversi skala lima, maka skor berada pada rentang 4,01 $<\mathrm{x} \leq 5,01$ dengan kualifikasi "sangat baik". Berdasarkan pada hasil tersebut, maka diketahui bahwa masing-masing RPP yang dikembangakan memiliki rata-rata skor validitas yang berkisar pada rentang 4,01 $<\mathrm{x} \leq 5,01$. Hal tersebut menunjukkan bahwa masing-masing RPP yang dikembangkan memiliki validitas dengan kualifikasi "sangat baik".

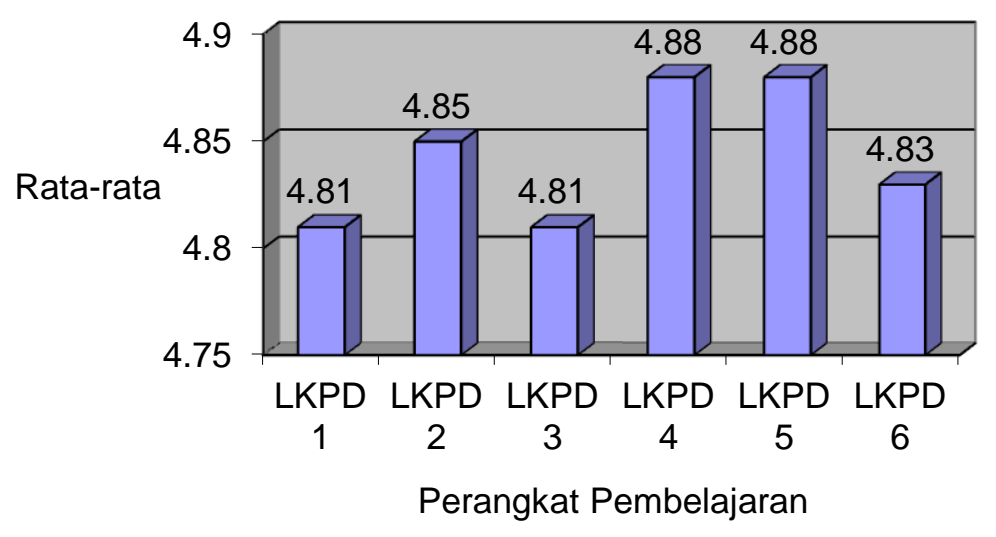

Gambar 2. Skor rata-rata validitas LKPD 
Validitas LKPD dapat dilihat melalui grafik yang disajikan pada Gambar 2. Berdasarkan grafik di atas, maka dapat diketahui rata-rata skor validitas masing-masing produk LKPD yang dikembangkan dalam penelitian sebagai berikut. 1) Rata-rata skor yang diperoleh pada LKPD 1 yaitu sebesar 4,81 apabila dikonversikan pada pedoman konversi skala lima, maka skor berada pada rentang 4,01 $<\mathrm{x} \leq 5,01$ dengan kualifikasi "sangat baik". 2) Rata-rata skor yang diperoleh pada LKPD 2 sebesar 4,85 apabila dikonversikan pada pedoman konversi skala lima, maka skor berada pada rentang $4,01<\mathrm{x} \leq$ 5,01 dengan kualifikasi "sangat baik". 3) Rata-rata skor yang diperoleh pada LKPD 3 sebesar 4,81 apabila dikonversikan pada pedoman konversi skala lima, maka skor berada pada rentang $4,01<\mathrm{x} \leq 5,01$ dengan kualifikasi "sangat baik". 4) Ratarata skor yang diperoleh pada LKPD 4 sebesar 4,88 apabila dikonversikan pada pedoman konversi skala lima, maka skor berada pada rentang 4,01 $<\mathrm{x} \leq 5,01$ dengan kualifikasi "sangat baik". 5) Rata-rata skor yang diperoleh pada LKPD 5 sebesar 4,88 apabila dikonversikan pada pedoman konversi skala lima, maka skor berada pada rentang 4,01 $<\mathrm{x} \leq 5,01$ dengan kualifikasi "sangat baik". 6) Rata-rata skor yang diperoleh pada LKPD 6 sebesar 4,83 apabila dikonversikan pada pedoman konversi skala lima, maka skor berada pada rentang 4,01 $<\mathrm{x} \leq 5,01$ dengan kualifikasi "sangat baik". Berdasarkan pada hasil tersebut, maka diketahui bahwa masing-masing LKPD memiliki rata-rata skor validitas pada berkisar pada rentang $4,01<\mathrm{x} \leq$ 5,01. Hal tersebut menunjukkan bahwa masing-masing LKPD yang dikembangkan memiliki validitas dengan kualifikasi "sangat baik".

Berdasarkan deskripsi hasil penelitian yang telah diuraikan sebelumnya, pengembangan perangkat pembelajaran inkuiri terbimbing berbasis aktivitas Higher Order Thinking (HOT) pada Tema 8 Subtema 1 kelas V SD dilakukan dengan menggunakan model ADDIE yang terdiri dari analyze, design, development, dan evaluation. Tahap implementation dan tahap evaluation pada model ADDIE tidak dilaksanakan pada penelitian ini karena adanya keterbatasan waktu penelitian. Model ADDIE merupakan salah satu model yang digunakan untuk merancang suatu pembelajaran (Barokati dan Anas, 2013). Pemilihan model ini didasari pada pertimbangan bahwa model ini mudah dipahami dan dikembangkan secara sistematik. Model ini dapat digunakan dalam berbagai macam bentuk pengembangan produk seperti model, strategi pembelajaran, metode pembelajaran, media dan bahan ajar. Model ADDIE berfungsi sebagai pedoman dalam membangun perangkat dan infrastruktur program pelatihan yang efektif, dinamis dan mendukung kinerja pelatihan itu sendiri (Sari, 2017). Dengan menggunakan model pengembangan ADDIE, perangkat yang dihasilkan akan sesuai dengan permasalahan yang dihadapi, kurikulum yang sedang dijalankan, kondisi siswa, dan materi pembelajaran (Hidayatulloh, 2015).

Pada tahap analyze dilakukan analisis kebutuhan, analisis karakteristik siswa, dan analisis kurikulum. Hasil kegiatan analisis yang dilakukan menunjukkan bahwa belum terdapat perangkat pembelajaran yang digunakan untuk menunjang pengembangan kemampuan HOT yang sesuai dengan karateristik siswa. Berdasarkan hal tersebut, maka perlu disusun perangkat pembelajaran yang mampu memenuhi kebutuhan dalam mengembangkan kemampuan HOT siswa. Pengembangan perangkat pembelajaran disesuaikan berdasarkan hasil analisis kebutuhan yang telah dilakukan (Pariatna, dkk., 2015).

Pada tahap design dilakukan perancangan perangkat pembelajaran inkuiri terbimbing berbasis aktivitas Higher Order Thinking (HOT) pada Tema 8 Subtema 1 kelas V SD yang meliputi silabus, RPP, dan LKPD. Penyusunan silabus dilakukan dengan unsur-unsur, yaitu 1) identitas sekolah sekolah, 2) kompetensi inti, 3) kompetensi dasar, 4) tema, 5) materi pokok, 6) pembelajaran, 7) penilaian, 8) alokasi waktu, dan 9) sumber belajar. Penyusunan RPP dilakukan dengan unsur-unsur, yaitu 1) identitas sekolah, 2) identitas mata pelajaranatau tema/subtema, 3) kelas/semester, 4) materi pokok, 5) alokasi waktu, 6) tujuan pembelajaran, 7) kompetensi dasar dan indikator pencapaian kompetensi, 8) materi pembelajaran, 9) metode pembelajaran, 10) media pembelajaran, 11) sumber belajar, 12) langah-langkah pembelajaran, dan 13) penilaian hasil belajar. Selanjutnya, penyusunan LKPD dilakukan dengan unsur-unsur, yaitu 1) sampul LKPD, 2) tujuan, 3) petunjuk kerja, 4) kegiatan siswa, dan 5) kesimpulan. Pada tahap development dilakukan pengembangan perangkat inkuiri terbimbing berbasis aktivitas Higher Order Thinking (HOT) yang meliputi silabus, RPP, dan LKPD untuk Tema 8 Subtema 1 kelas V SD. Setelah perangkat pembelajaran dikembangkan, kemudian dilakukan penilaian dengan pemberian kuesioner validitas kepada empat ahli pembelajaran yang terdiri dari dua orang guru dan dua orang dosen. Setelah dilakukan penilaian, diperoleh saran dan komentar dari ahli yang dapat akan digunakan sebagai bahan revisi untuk penyempurnaan perangkat pembelajaran. Hasi penilaian produk silabus diperoleh rata-rata skor sebesar 4,69, apabila dikonversikan dengan pedoman konversi skala lima maka skor tersebut berada pada rentang 4,01<x $\leq 5,01$ dengan kualifikasi "sangat baik". Masing-masing komponen pada silabus sebagian besar memperoleh rata-rata skor yaitu pada rentang $4,01<\mathrm{x} \leq 5,01$ dengan kualifikasi "sangat baik". Sedangkan pada komponen 10 rata-rata skor diperoleh sebesar 4,00, dengan kualifikasi "baik". Hal tersebut dikarenakan komponen 10 yakni sumber belajar yang dicantumkan kurang jelas dan perlu penambahan sumber belajar lainnya, sehingga untuk penyempurnaan pada komponen 10 maka perlu dilakukan revisi.

Hasil penilaian pada RPP yaitu rata-rata skor masing-masing komponen RPP sebagian besar pada rentang $4,01<\mathrm{x} \leq 5,01$ dengan kualifikasi "sangat baik". Namun beberapa komponen dalam RPP memperoleh rata-rata skor pada rentang 3,33<x $\leq$ 4,01 dengan kualifikasi "baik" yaitu pada komponen 13 dalam RPP 3, komponen 14 dalam RPP 2, 3, 4, dan 5, serta komponen 15 dalam RPP 1 dan 2. Rata-rata skor yang diperoleh pada RPP 1 yaitu sebesar 4,57, RPP 2 sebesar 4,68, RPP 3 sebesar 4,69, RPP 4 sebesar 4,77, RPP 5 sebesar 4,77, dan RPP 6 sebesar 4,78. Secara keseluruhan rata-rata skor validitas RPP yaitu 4,77 yang apabila dikonversikan dengan pedoman konversi skala lima skor rata-rata RPP berada pada rentang $4,01<\mathrm{x} \leq 5,01$ dengan kualifikasi "sangat baik".

Hasil penilaian pada LKPD yaitu masing-masing komponen pada seluruh LKPD memperoleh rata-rata skor yang berada pada rentang $4,01<\mathrm{x} \leq 5,01$. Hal tersebut menunjukkan bahwa masing-masing komponen LKPD memiliki kualifikasi "sangat baik", sehingga dinyatakan valid. Selanjutnya, rata-rata skor yang diperoleh pada masing-masing LKPD adalah sebagai berikut. LKPD 1 memperoleh rata-rata skor sebesar 4,81, LKPD 2 sebesar 4,85, LKPD 3 sebesar 4,81, LKPD 4 sebesar 4,88, LKPD 5 sebesar 4,88, dan LKPD 6 sebesar 4,83. Secara keseluruhan rata-rata skor validitas LKPD adalah 4,84. Berdasarkan pada tabel pedoman penilaian skala lima, skor 4,84 berada pada rentang $4,01<\mathrm{x} \leq 5,01$. Hal tersebut menunjukkan bahwa produk LKPD yang dikembangkan memiliki kualifikasi "Sangat Baik" dan telah valid. 


\section{Simpulan}

Berdasarkan hasil penelitian dan pembahasan maka dapat disimpulkan bahwa perangkat pembelajaran inkuiri terbimbing berbasis aktivitas Higher Order Thinking (HOT) pada Tema 8 Subtema 1 kelas V SD yang terdiri dari silabus, RPP, dan LKPD dinyatakan valid dengan tingkat validitas sangat baik. Hasil pengujian validitas menunjukkan: (1) rata-rata skor validasi produk silabus yaitu 4,69, dengan kualifikasi sangat baik, rata-rata skor validasi produk RPP yaitu 4,77 dengan kualifikasi sangat baik, rata-rata skor validasi produk LKPD yaitu 4.84 dengan kualifikasi sangat baik, (2) Perolehan hasil validitas perangkat pembelajaran berupa silabus, RPP, dan LKPD inkuiri terbimbing berbasis aktivitas Higher Order Thinking (HOT) pada Tema 8 Subtema 1 kelas V SD yaitu berada pada kualifikasi yang positif (melebihi kategori baik) menunjukkan bahwa perangkat pembelajaran yang telah dikembangkan memiliki tingkat validitas sangat baik sehingga layak untuk digunakan dalam pembelajaran.

Berdasarkan hasil penelitian yang telah dilakukan, adapun saran yang dapat disampaikan yaitu sebagai berikut. Pertama, guru hendaknya mampu memfasilitasi siswa untuk membangun pengetahuan dengan kemampuan HOT melalui penggunaan perangkat pem-belajaran yang dapat menunjang pengembangan kemampuan HOT siswa yang dalam hal ini perangkat pembelajaran inkuiri terbimbing berbasis aktivitas HOT. Kedua, kepala sekolah hendaknya mamfasilitasi guru untuk mengembangkan perangkat pembelajaran seperti memberikan kesempatan pada guru untuk mengikuti pelatihan menyusun perangkat pembelajaran sehingga mendukung peningkatan kualitas proses pembelajaran di sekolah. Ketiga, kepada peneliti lain, agar dapat dijadikan referensi dalam melakukan penelitian untuk mengembangkan produk sejenis dengan tema pembelajaran atau jenjang yang berbeda.

\section{Daftar Pustaka}

Barokati, N. dan F. Anas. 2013. "Pengembangan Pembelajaran berbasis Blended Learning pada $\quad$ Mata Kuliah Pemrograman Komputer (Studi Kasus: Unisda Lamongan)”. Jurnal Sistem Informasi, Vol. 4, No. 5 (hlm. 355).

Daryanto. 2014. Pendekatan Pembelajaran Saintifik Kurikulum 2013. Yogyakarta: Penerbit Gava Media.

Hidayatulloh, M. dan Madlazim. 2015. "Pengembangan Perangkat Pembelajaran Inkuiri Terbimbing Berorientasi Kurikulum 2013 dengan Melatihkan Ke- terampilan Proses Sains pada Materi Pengukuran". Jurnal Inovasi Pendidikan Fisika (JIPF), Vol. 4, No. 2 (hlm. 93-94).

Jamaluddin, dkk. 2018. "Pelatihan Penyusunan Instrumen Keterampilan Berpikir Tingkat Tinggi bagi Pendidik Mata Pelajaran IPA SMP di Kota Mataram”. Jurnal Pengabdian Magister Pendidikan

IPA, Vol. 1, No. 1 (hlm. 80).

Jauhar, M. 2011. Implementasi PAIKEM dari Behavioristik sampai Konstruktivistik. Jakarta: Prestasi Pustakaraya. Kemendikbud. 2016. Salinan Lampiran Permendikbud No. 22 Tahun 2016 tentang Standar Proses Pendidikan

Dasar dan Menengah. Jakarta: Kemendikbud.

Machin, A. 2014. "Implementasi Pendekatan Saintifik, Penanaman Karakter dan Konservasi pada Pembelajaran Materi Pertumbuh- an". Jurnal Pendidikan IPA Indonesia, Vol. 3, No.1 (hlm. 28).

Nasution, S. W. R. 2018. "Penerapan Model Inkuiri Terbimbing (Guided Inquiry) dalam Meningkat- kan Kemampuan Berpikir Kritis pada Pembelajaran Fisika”. Jurnal Education and Development, Vol. 3, No. 1 (hlm. 2).

Ningrat, S. P. \& M. Sumantri. 2019. "Kontribusi Gaya Belajar dan Motivasi Belajar terhadap Hasil Belajar Bahasa Indonesia Siswa Kelas V SD”. Journal of $\quad$ Education Technology, Vol. 2, No. 4 (hlm. 146).

Pariatna, I W. J., dkk. 2015. "Pengembangan Perangkat Pembelajaran Inkuiri Terbimbing pada Topik Laju Reaksi". Jurnal Wahana Matematika dan Sains, Vol. 9, No. 1 (hlm. 9-11)

Rofiah, E., dkk. 2013. "Penyusunan Instrumen Tes Kemampuan Berpikir Tingkat Tinggi Fisika pada Siswa SMP”. Jurnal Pendidikan Fisika, Vol. 1, No. 2 (hlm. 18).

Rudyanto, H. E. 2016. "Model Discovery Learning dengan Pendekatan Saintifik Bermuatan Karakter untuk Meningkatkan Kemampuan Berpikir Kreatif'. Premiere Educandum: Jurnal Pendidikan Dasar dan Pembelajaran, Vol. 4, No. 1 (hlm. 43).

Sari, B. K. 2017. "Desain Pembelajaran Model ADDIE dan Implementasinya Dengan Teknik Jigsaw". Makalah disajikan dalam Prosiding Seminar Nasional Pendidikan dengan Tema Desain Pembelajaran Di Era Asean Economic Community (AEC) untuk Pendidikan Indonesia Berkemajuan, Fakultas Keguruan dan Ilmu Pendidikan Universitas Muhammadiyah Sidoarjo.

Susanto, A. 2013. Teori Belajar $\quad$ Pembelajaran di Sekolah Dasar. Jakarta: Kencana Prenadamedia Group.

Sutrisno, D. \& H. Retnawati. 2018. "Korelasi Kemampuan Berpikir Tingkat Tinggi dan Prestasi Belajar Siswa MAN 3 Yogyakarta". Edumatica: Jurnal Pendidikan Matematika, Vol. 8, $\quad$ No. 1 (hlm. 17).

Tegeh, I M. dan I N. Jampel. 2017. MetodePenelitian Pengembangan. Singaraja: Universitas Pendidikan Ganesha. 